\title{
Reducing techno-anxiety in high school teachers by improving their ICT problem- solving skills
}

AQ1 Olga Revilla Muñoz ${ }^{\mathrm{a}}$ (), Francisco Alpiste Penalba ${ }^{\mathrm{a}}$, Joaquín Fernández Sánchez ${ }^{\mathrm{a}}$ and Olga C. Santos $^{\mathrm{b}}$ (1)

a Laboratori d'Aplicacions Multimèdia, Universitat Politécnica de Catalunya, Barcelona, Spain; baDeNu Research Group, Artificial Intelligence Depto, Computer Science School, UNED, Madrid, Spain

ABSTRACT

Teachers need to continuously update their information and communication technologies (ICT) knowledge, but they are usually not trained to deal with the problems arising from their use. In fact, studies in the literature report techno-anxiety (i.e. unpleasant physiological activation and discomfort due to present or future use of ICT) in teachers. Thus, the goal of this action research is to study if teachers' techno-anxiety can be reduced by increasing their ability to solve technological problems. An inter-subject experiment has been carried out with 46 teachers. High school teachers were chosen because they are digital immigrants, while at the moment of this research their students are digital natives (born around year 2000). Since we could not find any specific training for teachers to increase their resolution skills of technological problems, in order to apply the treatment for our study, we have designed and deployed an online course about ICT problem-solving skills based on the 70/20/10 model for learning and development. Results show the success of the course when it comes to increasing the ICT problem-solving skills and to reducing techno-anxiety.

\section{Introduction and background}

Computer anxiety is a widely occurring phenomenon that has been studied in the literature since the introduction of computers into workplaces, showing that users who know little about computers are more likely to have anxiety about them (Torkzadeh and Angulo 1992). When Information and Communication Technologies (ICT) were introduced in schools, teachers were very much concerned with using them in class, specifically learning to use them and dealing with their failures (Rosen and Weil 1995). The literature has for long reported that very often teachers do not have positive attitudes towards computers because they fear using them in their classes (Hardy 1998), do not feel well prepared to integrate technology into classroom instruction and have low level of confidence in using the technology (Becta 2004). In fact, teachers are worried about showing their students their lack of technological competence (Larner and Timberlake 1995), while students (who experience daily interaction with a wide range of technology) are increasingly placing demands on teachers, expecting them to be experts and a role model in the area of computer usage (Guha 2000).

There exist many survey-based studies in the literature that have reported along time that teachers suffer from computer anxiety (also called techno-anxiety), an
ARTICLE HISTORY

Received 1 November 2015

Revised 24 April 2016

Accepted 1 August 2016

\section{KEYWORDS}

Techno-anxiety; computer anxiety; teachers; problemsolving skills; affective computing unpleasant physiological activation and discomfort due to the present or future use of ICT and which is considered one of the components of stress (Salanova, Llorens, and Cifre 2013). These studies are carried out from responses of teachers to questionnaires and they focus on understanding the phenomenon (e.g. Kotrlik and Smith 1988; Russell and Bradley 1997; Chou 2003; Paraskeva, Bouta, and Papagianni 2008; Agbatogun 2010; Rahimi and Yadollahi 2011; Bolandifar and Noordin 2015). Similar studies are also carried on preservice teachers - or teachers under training (e.g. Rovai and Childress 2003; Ursava and Karal 2009).

ICT usage creates new situations in which teachers do not always have the required skills to deal with them. Thus, teachers cannot help students develop a competence that they themselves do not possess in depth (Fernandez-Cruz and Fernandez-Diaz 2016). Continuous adaptation is required, and to be and to feel in control, this requires strategies for detecting and solving problems in an efficient and effective manner (Lazarus 2007). Simply introducing ICT in the classroom is useless unless teachers know how to use them and take advantage of their abilities (Sabzian and Gilakjani 2013).

In order to reduce techno-anxiety in teachers, training programmes that provide them with technology skills during their professional development have been

AQ2 CONTACT Olga Revilla Muñoz olga@itakora.com

1 ๑ 2016 Informa UK Limited, trading as Taylor \& Francis Group 
suggested by several authors (e.g. Russell and Bradley 1997; Bolandifar and Noordin 2015), with special emphasis in explaining problem-solving techniques (Paraskeva, Bouta, and Papagianni 2008). However, we have not found any study in the literature that has demonstrated benefits on reducing techno-anxiety by training teachers on ICT problem-solving skills and resolution techniques.

Recent studies with a large sample of teachers (i.e. 80 schools and 1433 teachers in the Community of Madrid, Spain) show a significant difference between optimal ICT skills and the low skills that teachers really have to develop learning activities with technological tools for their students, showing the need for teachers to be trained in the application of digital competence in the classroom (Fernandez-Cruz and Fernandez-Diaz 2016). In our view, if teachers are given the skills to solve ICT problems (and not only 'recipes' to solve very specific technological problems), they can improve not only their level of competence, but also their level of confidence in using the technology and thus, reduce their physiological activation and discomfort associated with their fear of using technology in class. Thus, in this research we have tested the following hypothesis:

If high school teachers improve their ICT problem-solving skills, their techno-anxiety level is reduced.

The selection of high school teachers as target group is due to the fact that their students (13-18 years old) are digital natives at the moment of this research; that is, they have grown in contact with technology along their whole life, and thus, belong to the so-called Generation $\mathrm{Z}$ (Schroer 2008). In turn, teachers are digital immigrants (Prensky 2001). In addition, secondary school teachers are also the target of some of the previous questionnaire-based studies (Chou 2003; Paraskeva, Bouta, and Papagianni 2008; Agbatogun 2010).

From 2012 to 2014 we carried out a survey of ICT support programmes available for teachers in Spain. The programmes reviewed are reported in the Appendix classified into the following 5 categories (see Table A1 for their description): (i) initial education for teachers (13 subjects in the Masters from 5 universities randomly selected from the website of the Spanish Ministry of Education, as compiled in Table A2), (ii) lifelong learning for teachers (24 programmes grouped in 4 categories, as compiled in Table A3), (iii) governmental ICT promotion in schools (6 programmes, as compiled in Table A4), (iv) private ICT promotion for teachers (2 programmes, as compiled in Table A5); and (v) communities of practice (10 communities of practices, as compiled in Table A6). None of these programmes focused on ICT problem-solving. Hence, since we could not find any specific training for teachers to increase their resolution skills of technological problems, we have designed and deployed an online course about how to train ICT problem-solving skills, which is described in this paper.

In addition, an online support programme based on questions and answers has been created, where teachers can pose their problems on ICT and they can receive personalised solutions from other teachers taking into account their ICT profile, which consists in (i) the teacher's skills in ICT problem-solving (i.e. level, copying technique in terms of active vs. passive, and priority preference in terms of time vs. easiness), (ii) the teacher's competences in ICT (i.e. digital illiterate, basic, advanced, and proficient), and (iii) the teacher's attitude towards ICT (i.e. innovation predisposition, technoanxiety, and techno-fatigue), as well as specific features of the solution, such as (a) efficacy (number of users who resolved the problem with the solution), (b) duration (time taken to complete the instructions), (c) difficulty (how complicated it is to follow the instructions for an average user), and (d) needed attitude (i.e. how should the mind-set of the person be to apply the solution: active vs. passive). A detailed description of the support programme is reported elsewhere (Revilla Muñoz, Alpiste Penalba, and Fernández Sánchez 2016).

The paper is structured as follows. In the next section, we describe the methodology followed to design the online course. After that, the resulting online course is presented and the results from an inter-subject experiment are shown and discussed in relation to the hypothesis posed. Finally, conclusions, limitations, and open issues are summarised, followed by a description of future work aimed to integrate affective computing to detect anxiety states in teachers during their ICT problem-solving process and allow the system to react accordingly.

\section{Methodology}

The investigation carried out consists in action research, an approach focused on social change, where participants are involved in the study to improve their social situation at the same time that they are aware that the treatment (Lewin 1946) helps them to improve. Among the different types of action research (Carr and AQ3 Kemmis 1986), this work follows the types 'technique' A and 'practice': 'Technique', because the researcher is an external expert who teaches her premises to the participants; 'Practice', because it also aims to transform participants' awareness, promoting participation and self-reflection. This type of research is iterative, which 
means that the results of the research feed the planning of the next research back.

The treatment consists in an online course on ICT problem-solving. The aim of the course is to teach how to solve both convergent and divergent problems regarding ICT use. According to Fogler, Leblanc, and Rizzo (2013), problems can be classified into convergent (having only one or a reduced set of defined solutions) and divergent (the number of solutions is unknown, and depend on the creativity of the person, and they are usually related to the use of technology). The Mathematics Approach (Polya 2014) and the Information Problem-Solving Approach (the Big6 skills) (Eisenberg and Berkowitz 2011) have been used in the course to teach strategies for solving convergent problems. For divergent problems, the Creative Problem-Solving strategy (Osborn 2007) has been taught.

The goal of the course is that participants achieve abilities and knowledge that allow them to apply resolution strategies as well as to modify their perception and feelings towards the technology. Thus, it follows a cognitive restructure approach, increasing the resources and capabilities of the teachers by making the teachers reduce their perception of problems' impact and severity, and at the same time increase the coping skills. The course does not only focus on achieving the correct solution for the problem, but also on making the participant understand the process to solve it. The goal is that the participant assimilates a way of acting by solving problems that she can use in different aspects of her life, including her work activity as a teacher.

The course combines technological alphabetisation (i.e. to know and use ICT properly) and problem resolution skills (for both convergent and divergent problems). Framed in the lifelong learning paradigm (Aspin and Chapman 2007), the course was delivered online. In order to facilitate the learning process as suggested in Muresan and Gogu (2013), the course was developed as follows: (i) using a simple design (so people with low technological abilities could follow it), (ii) real problems were used and described in an enjoyable way, (iii) participants were allowed to follow their own pace, and (iv) communication tools (both with the organisers and the other participants) were provided. In addition, the course (as well as the aforementioned Q\&A support programme) were delivered and designed in an accessible and responsive way, following World Wide Web AQ4 Consortium (W3C) standards so it can be taken in all

- types of devices, systems, and browsers (Revilla 2010; Marcotte 2011).

The course follows the 70/20/10 model for learning and development (Lombardo and Eichinger 1996) that applies the problem-based learning approach and focuses on adult learning. It grounds on that the educational and emotional development usually starts by discovering a need and continues with the motivation required to satisfy it. It implies an independent and self-directed learning, typical of online learning and adult learning. It defines the ratio 70:20:10, which states that knowledge is acquired through three ways: $10 \%$ through classical learning, 20\% through feedback, and mainly $(70 \%)$ through experience. Thus, this model pushes students to experiment independently and selfdirected in solving problems through different techniques. According to Jennings and Wargnier (2011), the success of the model relies in that participants internalise and apply what they have learnt in their own context, and thus, it requires an active role by participants. This means that it can be learnt 'how to solve problems' by 'solving problems'. In the end, it fosters internal reflection. Nonetheless, it needs to be noted that the model should not be considered to be a prescriptive model and the given ratio is neither a scientific fact nor a recipe for how best to develop people' (Jefferson and Pollock 2014), and it is difficult to measure the real impact and effectiveness of this methodology in comparison with other approaches (Kajewski and Valerie 2013), resulting in the lack of empirical data that support its effectiveness.

An action research methodological approach involves iteration cycles. Besides, our contributions follow the User-centred Design (UCD) methodology (ISO 2010), which is also iterative. Each UCD cycle considers the following steps: (1) identify users' needs; (2) specify the context of use; (3) produce requirements; (4) produce design solutions; and (5) evaluate solutions to verify that the requirements are met. At this point in our research, we have carried out two iterations (an online course and a support programme), and we are planning the next one (non-obtrusive affective data gathering and personalised support delivery). This paper focuses on the first iteration, that is, the online course.

\section{Online course on resolution skills for ICT problems}

The first iteration carried out following the research action methodology consisted in the design and delivery of an online course to teach high school teachers resolution skills for technological problems. The course is based on the 70:20:10 model for learning and development (Lombardo and Eichinger 1996) that facilitates internalising problem-solving skills. As summarised in Table 1, the course consists in 3 units (i.e. the technology, the problems, and the solutions), and it is designed to take about 100 hours. There is a practical activity for 
Table 1. Course design.

\begin{tabular}{lll}
\hline & Course elements & \multicolumn{1}{c}{ Goal } \\
\hline Contents & $\begin{array}{l}\text { Unit 1. The technology } \\
\text { Unit 2. The problems } \\
\text { Unit 3. The solutions } \\
\text { Unit 1. The technology } \\
\text { Unit 2. The problems } \\
\text { Unit 3. The solutions }\end{array}$ & $\begin{array}{l}\text { Technological alphabetisation } \\
\text { Problem resolution skills }\end{array}$ \\
$\begin{array}{lll}\text { Additional contents } \\
\begin{array}{l}\text { Forum } \\
\text { Final exam }\end{array}\end{array}$ & $\begin{array}{l}\text { Technological alphabetisation } \\
\text { Problem resolution skills }\end{array}$ \\
\hline
\end{tabular}

each lesson where participants have to reflect on the contents explained in it, applying them to their life and real context. Each activity was corrected in less than 24 hours, providing a comment analysing the work done. In order to pass the course, participants have to carry out all practical activities and score over $50 \%$ in a final exam.
The course has been deployed in Moodle, a well-known and widely used open-source learning environment. The presentation layer was customised by developing a specific template for the course. Figure 1 shows the main page of the course, with the first unit (the technology) enlarged to show its four lessons and their activities.

Figure 1. First unit with four lessons and corresponding activities. 
The course was passed by 23 participants, who made a total of 7785 interactions in the Moodle platform while browsing and downloading contents, activities delivery, forum participation, and accessing user data. These participants who passed the course were asked for feedback at the end of the course. On a 5-point Likert scale, participants liked the course ( $\mathrm{Avg}=4.57$; $\mathrm{StD}=0.51$ ), considered that contents were new and have not been seen in other courses $(\mathrm{Avg}=4.52 ; \mathrm{StD}=0.51)$, and found the contents useful ( $\mathrm{Avg}=4.57 ; \mathrm{StD}=0.51)$. In addition, the Net Promoter Score (Reichheld 2003) was computed for all participants, with the result that all students who passed the course scored as promotors (i.e. loyal and enthusiast users who will go back to take the course and recommend it to a friend). Qualitative information was also recorded through a questionnaire. Feedback received showed positive perceptions for the course (interesting, useful, and well organised). The most valuable aspects of the course were easiness to understand the course and the success of the methodology to achieve course objectives.

\subsection{Evaluation design}

We have analysed the benefits of this online course with a study that involved 46 high school teachers. For the experimentation, 2 groups were formed, with 23 teachers in each one: (1) the experimental group that received the treatment (i.e. the online course) and (2) the control group that did not receive it. Both groups had a pretest (initial) and a post-test (final) that were filled out, respectively, before and after the online course was carried out in the experimental group. These tests measured (i) the skills for solving technological problems, and (ii) the techno-anxiety level.

In order to measure the ICT problem resolution skills, participants were asked to propose solutions to six ICTrelated problems, four convergent related to technology operation and two divergent on the impact of people. Since questions are open, the analysis of the responses (i.e. solution proposed to the given problem) was done using the methodology proposed in Méndez et al. (2011), which consists in the analysis and evaluation of the following six competence criteria: (1) comprehension of the problem, (2) application of the method, (3) justification and clarity, (4) results, (5) efficiency of the solution, and (6) critical analysis. The numerical scoring scale used to evaluate each criterion for a given response was the following: insufficient ( $0-4$ points); sufficient (46 points); advanced (6-8 points); and excellent (8-10). Final scoring for each response is the average of the scores per each of the six indicators. The ICT skill resolution capability of each participant is the average of the scores of the six responses, ranging this final score from 0 to 10 .

Techno-anxiety level was measured using the RED model (Resources-Experiences-Demands) (Salanova et al. 2007). Although there are several instruments to measure different dimensions related to techno-stress, and in particular, the Computer Anxiety Rating Scale (Heinssen, Glass, and Knight 1987), the RED questionnaire was chosen for this research because of its technology agnosticism, methodological validity (Cronbach alpha between 0.70 and 0.96 ) according to Ventura, Llorens, and Salanoya (2006), and simplicity. Indeed, this tool is used and recommended by the Spanish Work and Social Affairs Ministry to measure techno-stress in Spanish workers (Salanova et al. 2007). The questionnaire consists of 16 items grouped into 4 concepts focused on the consequences of the use of technology: scepticism, fatigue, anxiety, and ineffectiveness. A 7 point Likert scale $(0=$ never/nothing to $6=$ always/everyday) is used to measure each item. The score of each concept is the average of its four items. Techno-anxiety level is computed by adding the values of three of these concepts, namely, anxiety, scepticism, and ineffectiveness. Thus, the range of techno-anxiety level goes from 0 to 18 .

The course was run during six weeks. Participants were recruited using social networks and personal contacts and they gave their consent to data gathering following the Spanish Law 15/1999 (Gobierno de España 1999). Demographics of the participants $(n=46)$ were the following: experimental group $(n=23$; male $=43 \%$; age range $=23-55$ years; no children $=39 \%$; $96 \%$ with more than 5 years of teaching experience; $74 \%$ with low or none level of English; majority and lazy technology adopters $\left.^{1}=70 \%\right)$; control group $(n=23$; male $=$ $57 \%$; age range $23-60$ years; no children $=49 \%$; $83 \%$ with more than 5 years of teaching experience; $78 \%$ with low or none level of English; majority and lazy technology adopters $=61 \%$ ).

\subsection{Results}

Two aspects have been analysed: (1) the impact of the course on the problem resolution skills and (2) the impact on the techno-anxiety level.

Table 2 shows the results of the statistical analysis carried out with the data collected in the corresponding four sets of samples: experimental (exp) vs. control (crl); initial $\left({ }_{1}\right)$ vs. final $\left({ }_{2}\right)$; and for these two aspects analysed (i.e. problem resolution skills and techno-anxiety level). Normality of the data was assessed with the ShapiroWilk test. In five of the eight sets, the null hypothesis is rejected and, thus, there is evidence that the data tested 
505

AQ25 Table 2. Statistical analysis carried out on the data.

\begin{tabular}{|c|c|c|c|c|c|c|}
\hline & \multicolumn{3}{|c|}{ Experimental group } & \multicolumn{3}{|c|}{ Control group } \\
\hline & Initial & Final & Final-Initial & Initial & Final & Final-Initial \\
\hline \multicolumn{7}{|c|}{ Problem resolution skills } \\
\hline Total & 126.40 & 145.05 & 18.65 & 118.80 & 116.34 & -2.46 \\
\hline$M$ (mean) & 5.50 & 6.31 & 0.81 & 5.17 & 5.06 & -0.11 \\
\hline SD & 1.35 & 1.15 & 1.86 & 1.33 & 1.06 & 1.68 \\
\hline Shapiro-Wilk test & $p=.626$ & $p=.561$ & $p=.806$ & $p=.580$ & $p=.030^{*}$ & $p=.505$ \\
\hline $\begin{array}{l}\text { One-sample } \\
\text { Student's } t \text {-test } \\
\left(p=.048^{*}\right)\end{array}$ & & & $x^{*}$ & & & \\
\hline $\begin{array}{l}\text { One-sample } \\
\text { Student's } t \text {-test } \\
(p=.762)\end{array}$ & & & & & & $x$ \\
\hline $\begin{array}{l}\text { Kruskal-Wallis } \\
\qquad(p=.583)\end{array}$ & $x$ & & & & & \\
\hline $\begin{array}{l}\text { Kruskal-Wallis } \\
\qquad\left(p=.001^{*}\right)\end{array}$ & & $x^{*}$ & & & $x^{*}$ & \\
\hline \multicolumn{7}{|l|}{ Techno-anxiety level } \\
\hline Total & 58.25 & 37.50 & & 55.25 & 63.50 & 8.25 \\
\hline$M$ (mean) & 2.53 & 1.63 & 0.9 & 2.40 & 2.76 & 0.36 \\
\hline SD & 2.77 & 1.74 & 2.04 & 2.58 & 2.45 & 3.68 \\
\hline Shapiro-Wilk test & $p=.001^{*}$ & $p=.003^{*}$ & & & $p=.027^{*}$ & $p=.410$ \\
\hline $\begin{array}{l}\text { One-sample } \\
\text { Student's } t \text {-test } \\
\left(p=.046^{*}\right)\end{array}$ & & & & & & \\
\hline $\begin{array}{l}\text { One-sample } \\
\text { Student's } t \text {-test } \\
(p=.645)\end{array}$ & & & & & & $x$ \\
\hline $\begin{array}{l}\text { Kruskal-Wallis } \\
\qquad(p=.741)\end{array}$ & $x$ & & & & & \\
\hline $\begin{array}{l}\text { Kruskal-Wallis } \\
(p=.092)\end{array}$ & & & & & $\mathrm{x}$ & \\
\hline
\end{tabular}

Notes: ${ }^{*}=$ Significance level $p<.05 ;{ }^{\prime} x^{\prime}$ identifies the group (or pair of groups) compared in the corresponding statistical test.

are not from a normally distributed population. Nevertheless, when computing the difference between the means at the end and at the beginning (final-initial), then samples do not pass the Shapiro-Wilk test and can be considered from a normal distribution. For those samples for which the Shapiro-Wilk test was not significant, and thus, normality could be assumed, parametric analysis with the Student's $t$-test is carried out. When samples are not from a normal distribution, non-parametric analysis is carried out. In particular, the Kruskal-Wallis test was used to compare the control and experimental groups in each of the moments where the variables were measured (initial and final), since in this case samples were independent. The confidence level used is $95 \%$. Statistical significance is considered if $p<.05$.

\subsubsection{Impact of the course on the technological} problem solving skills

Regarding the impact of the course on the ICT problem resolution skills, measures taken in both groups before the course started are not statistically significant with the Kruskal-Wallis test $\left(M \exp _{1}=5.50 ; \operatorname{SDexp}_{1}=1.35\right.$; $\left.M \mathrm{crl}_{1}=5.17 ; \mathrm{SDcrl}_{1}=1.33 ; p=.583\right)$, showing that both groups have similar initial values, but there is a statistically significant difference when compared at the end $\left(M \exp _{2}=6.31 ; \mathrm{SDexp}_{2}=1.15 ; \mathrm{Mcrl}_{2}=5.06 ; \mathrm{SDcrl}_{2}=\right.$ $1.06 ; p=.001)$, showing that only the experimental group improved. In addition, when analysing the statistical significance of the difference of the means in each of the groups with the one-sample Student's $t$-test, there is a significant difference in the evolution of the experimental group $(M \exp =0.81 ; \mathrm{SDexp}=1.86 ; p=.048)$ but not

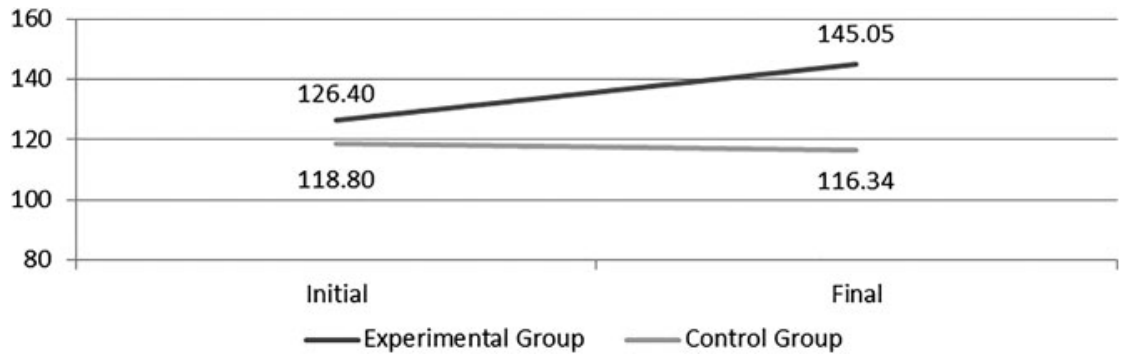

Figure 2. Total scores for problem resolution skills in each group. 


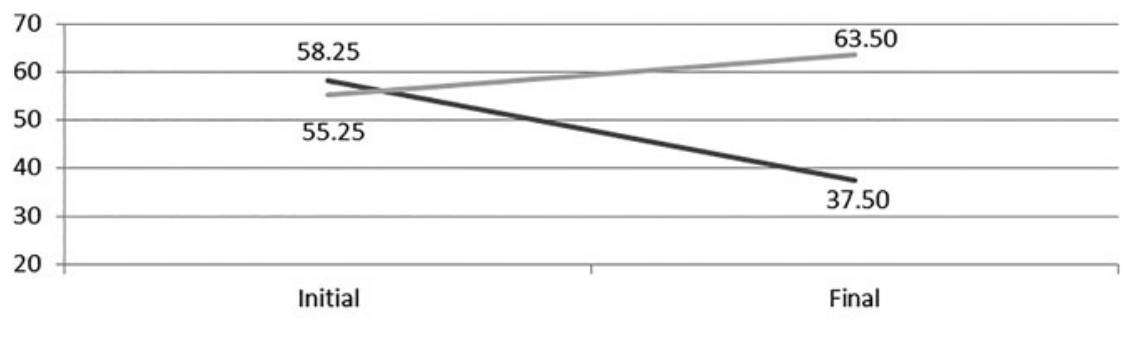

-Experimental Group

Figure 3. Total scores for techno-anxiety in each group.

in the evolution of the control group $(M c r l=-0.11$; SDcrl $=1.68 ; p=.762$ ). Thus, it can be said that the course has an impact on the ICT problem resolution skills.

Figure 2 shows the total scores in both groups at the beginning (initial) and at the end (final) of the study. It can be seen that while the scores in the problem resolution skills in the control group do not change much $(-2.46)$, in fact, they decrease slightly; but in the experimental group they increase in a larger amount $(+18.65)$, which is in line with the statistical significance obtained above.

\subsubsection{Impact of the course on the techno-anxiety level}

Regarding the techno-anxiety level, both groups also have a similar initial level since measures taken in both groups before the course started are not statistically significant with the Kruskal-Wallis test $\left(M \exp _{1}=2.53\right.$; $\left.\mathrm{SDexp}_{1}=2.77 ; \mathrm{Mcrl}_{1}=2.40 ; \mathrm{SDcrl}_{1}=2.58 ; p=.741\right)$. In turn, there is some difference at the end of the course as the techno-anxiety level is lower in the experimental group, but not significantly different with $p<.05$ $\left(M \exp _{2}=1.63 ; \quad \mathrm{SDexp}_{2}=1.74 ; \quad \mathrm{Mcrl}_{2}=2.76 ; \mathrm{SDcrl}_{2}=\right.$
2.45; $p=.092$ ). Nonetheless, when analysing the statistical significance of the difference of the means in each of the groups with the one-sample Student's $t$-test, there is a significant difference in the evolution of the experimental group $(M \exp =-0.90 ; S D \exp =2.04 ; p=.46)$, and not in the evolution of the control group $(M c r l=-0.36$; SDcrl $=3.68 ; p=.645$ ). Thus, it can be said that the course has also an impact on the techno-anxiety level, causing its reduction.

The total scores in both groups show a decrease in the experimental group (-20.75), while in the control group there is a small increase $(+8.25)$, as shown in Figure 3. This confirms previous analysis, accounting that the experimental group has decreased their techno-anxiety level with statistical significance, suggesting that the treatment (i.e. the course) was responsible for this impact.

\section{Discussion}

Although the findings obtained in the evaluation of the course are to be taken into account with care due to the small number of participants $(n=46)$ and the convenience sample (i.e. participants collected through social networks), they can suggest that the course was

$\Delta$ Experimental-Initial

- Experimental - Final

ICT Problem Solving Skills

6

- Control - Initial

- Control - Final

Lineal (All)

Figure 4. Relationship between techno-anxiety (range 0-18) and resolution skills of technological problems (range 0-10). 


\subsection{Contributions}

The main objective of the course was to provide cognitive and attitudinal tools to allow participants in the study (i.e. high school teachers) solve and prevent ICT problems by reducing the impact perception and severity. The 70/20/10 model for learning and development (specific for adult online learning) was used to make participants internalise and apply what they have learnt in their lives, as $70 \%$ comes from their own experience, $20 \%$ from others' experience, and 10\% from classical learning. The course is grounded in two pillars: technological alphabetisation (as a reflexion point on technology and as a tool to adapt to the environment) and problem resolution skills (where participants learned to choose and apply the most appropriate resolution method in each case).

In the study reported, 23 participants carried out the course. Problem-solving skills and techno-anxiety level were compared to another 23 participants who did not take the course. Statistically significant differences were obtained, showing that the problem resolution skills improved and the techno-anxiety level decreased in the group that took the course.

\subsection{Limitations and open issues}

Several limitations have been identified in this study. First, the number of participants might be considered low (at least compared to those questionnaire-based studies) and were selected with convenience sample from social networks. The reason for this was the need AQ5 to gather high school teachers who would like to be involved in a long-term course during a longitudinal field study. This makes the difference from the questionnaire-based studies reported in Section 1, where the effort required to fill in a questionnaire is much lower, and thus the number of participants is usually several hundreds and is usually collected from large databases of teachers. One consequence of this small and convenience sample could be that all participants scored as promotors, as well as the low levels of techno-anxiety measured. Further studies with a larger number of participants would be needed to clarify these issues. It would also be of interest to identify in more detail the user profile of those who followed and successfully finished the course, so specific efforts can be made to attract those not willing to take the course.

As a second limitation, the study was carried out in Spain, but in our view it can extrapolate to other countries with a similar situation to Spanish high school teachers. In this respect, one of the main causes of sick leave among high school teachers in Spain is psychological aspects (12.2\%) (Sánchez 2008). In fact, among the psychological illnesses more common in this group are those resulting from stress (Moriana Elvira and Herruzo Cabrera 2004). 
In the third place, the teachers sample belonged to high school degree, where the gap between digital natives (students) and digital immigrants (teachers) is higher. There might be differences when this barrier is reduced (e.g. when teachers are digital natives in the future). Thus, studies with other teachers of other educational levels would be desirable.

Fourth, it might be of interest to research if there are also benefits of problem skill resolution in other professions such as social workers (Choi, Ligon, and Ward 2002).

Fifth, this study has focused on techno-anxiety, but other variables related to techno-stress can also be measured (e.g. techno-fatigue) with the RED questionnaire (Salanova et al. 2007). In fact, although there was a statistically significant difference regarding the improvement of the problem resolution skills and the techno-anxiety level in the group that took the course, a low and negative correlation was found between both variables. This may suggest that there might be other variables involved that also affect techno-anxiety in high school teachers, which should be considered in further studies. In this sense, the approach for the following action research step is to take into account affective computing, which means that a wider sample of affective states can be automatically detected (Santos 2016).

In addition, it might be of interest to analyse self-efficacy feelings (Wilfong 2006) in the teachers since, according to Salanova, Llorens, and Cifre (2013), when workers get social support from colleagues while working with ICT, they feel inefficacious, but reasons are not clear (they could not solve the problems by themselves, or they are obliged to reciprocate when the person who helped has a problem in the future). The analysis of self-efficacy feelings might also show an attitude change 'ICT is hard' vs. 'I can manage with ICT problems' if the training is successful. The content itself may not be so important, as ICT changes all the time, thus appropriate attitude and self-learning skills might result to be key to cope with the new technology that is constantly being introduced in the classrooms.

\subsection{Future work}

In our view, future research should take into account affective computing and emerging technologies around Internet of Things, such as wearable devices and ambient intelligence, to support teachers in scenarios such as the following:

A teacher, who wears a smartwatch that measures her pulse (heart rate) and sweeting (galvanic skin response), gets close to a printer with the intention to gather a document she has sent to print, but the paper does not appear and the printer shows an error message. The system can detect - using a multimodal data mining approach that processes the signals collected with the smartwatch (i.e., heart rate, galvanic skin response) changes in her physiological signals which correspond to a significant increase in her anxiety level. In addition, taking advantage of the Internet of Things connectivity, the system knows that the printer nearby the teacher is not working properly and has displayed an error message. The teachers physiological reaction might suggest that she is not emotionally prepared to deal with the ICT related problem in the printer and would require a personalized support to deal with it, which can be provided in a multisensorial way taking advantage of ambient intelligence (for instance, in order to take the teacher to a more relaxed situation, the light of the room can be changed to blue which is the favourite colour of the teacher, and her smartphone can play a chill-out song from the teachers' playlist).

This scenario suggests that biofeedback technology can be used to detect anxiety in the teacher without disturbing her (Wilfong 2006). In this way, the way the teacher interacts with the environment can be drastically changed, as the environment might be able to identify the teacher's need and the reason for help by its own. In particular, affective states can be automatically detected by combining several data sources (Calvo and D'Mello 2010), which can take advantage of multimodal data mining techniques (Salmeron-Majadas et al. 2015). Continuous and context-aware monitoring of human physiological parameters in a non-intrusive way has only been possible with the recent development of wearable sensors such as smart watches, bracelets, and t-shirts (Mukhopadhyay 2015).

Automatic detection of affective states can allow providing personalised support at work for stress management (Bakker et al. 2012). For this, strategies to reduce techno-anxiety are to be provided while the teacher is trying to solve the problem with the printer. As proposed in Santos et al. (2016), sensorial feedback can be provided through the environment with ambient intelligence techniques to modify the teacher's emotional state without interrupting her activity (i.e. trying to solve the technological problem, in this case, using the printer). In particular, the environment itself could interact with the user through different sensorial channels, such as sight (lights), hearing (sound), or touch (vibration). In addition, problem resolution strategies and instructions on how to use the printer could be displayed with augmented reality. Support opportunities in this scenario can be identified with Tutor Oriented Recommendations Modeling for Educational Systems (TORMES) methodology (Santos and Boticario 2015) AQ6 by involving teachers in the elicitation process using UCD techniques and (big) data mining analysis. 6 


\section{Note}

1. According to the Innovation Diffusion Theory (Rogers 1962).

\section{AQ7 Disclosure statement}

No potential conflict of interest was reported by the authors.

\section{ORCiD}

Olga Revilla Muñoz (D) http://orcid.org/0000-0001-8605-2861

Olga C. Santos (iD http://orcid.org/0000-0002-9281-4209

\section{AQ8 References}

Agbatogun, A. 2010. "Self-concept, Computer Anxiety, Gender and Attitude towards Interactive Computer Technologies: A Predictive Study among Nigerian Teachers." International Journal of Education and Development Using ICT 6 (2): 55-68.

Aspin, D. N., and J. D. Chapman. 2007. "Lifelong Learning Concepts and Conceptions." In Philosophical Perspectives on Lifelong Learning, edited by David N. Aspin 19-38. Springer. http://link.springer.com/chapter/10.1007\%2F978-

AQ9 1-4020-6193-6_1

^ Bakker, J., L. Holenderski, R. Kocielnik, M. Pechenizkiy, and N. Sidorova. 2012. “Stess@Work: From Measuring Stress to its Understanding, Prediction and Handling with Personalized Coaching." In Proceedings of the 2nd ACM SIGHIT International Health Informatics Symposium (IHI '12), 673-678. New York, NY: ACM.

Becta. 2004. A Review of the Research Literature on Barriers to the Uptake of Ict by Teachers. British Educational Communications and Technology Agency. http://dera.ioe. ac.uk/1603/1/becta_2004_barrierstouptake_litrev.pdf.

Bolandifar, S., and N. Noordin. June 2015. "Computer Anxiety and Attitudes toward Using Internet in English Language Classes among Iranian Postgraduate Student Teachers.” Pertanika Journal of Social Sciences \& Humanities 23 (2): 355-374.

Calvo, R. A., and S. K. D’Mello. 2010. “Affect Detection: An Interdisciplinary Review of Models, Methods, and Their Applications." IEEE Transactions on Affective Computing 1 (1): 18-37.

940 Carr, W., and S. Kemmis. 1986. Becoming Critical: Education Knowledge and Action Research. London: Falmer.

Choi, G., J. Ligon, and J. Ward. 2002. "Computer Anxiety and Social Workers: Differences by Access, Use, and Training."

AQ12 Journal of Technology in Human Services 19 (1): 1-2.

1 Chou, C. 2003. "Incidences and Correlates of Internet Anxiety among High School Teachers in Taiwan." Computers in Human Behavior 19 (6): 731-749.

Eisenberg, M., and R. Berkowitz. 2011. The Big6 Workshop Handbook: Implementation \& Impact. Santa Barbara, CA:

AQ13 Linworth.

1 Fernandez-Cruz, F. J., and M. J. Fernandez-Diaz. 2016. "Generation Z's Teachers and their Digital Skills." Comunicar 46: 97-105.

Fogler, H. S., S. E. Leblanc, and B. Rizzo. 2013. Strategies for Creative Problem Solving. 3rd ed. Prentice Hall.
https://www.pearsonhighered.com/program/FoglerStrategies-for-Creative-Problem-Solving-3rd-Edition/ PGM300967.html.

Gobierno de España. 14 de 12 de 1999. "Ley Orgánica 15/1999, de 13 de diciembre, de Protección de Datos de Carácter Personal.” Boletín Oficial del Estado 298: 43088-43099.

Guha, S. 2000. "Are we all Technically Prepared? Teachers' Perspectives on the Causes of Comfort or Discomfort in Using Computers at Elementary Grade Teaching." Paper presented at the annual meeting of the National Association for the Education of Young Children, Atlanta, GA, November 8-11.

Hardy, J. V. 1998. "Teacher Attitudes toward and Knowledge of Computer Technology." Computers in the Schools 14: 119-136.

Heinssen, R., C. Glass, and L. Knight. 1987. “Assessing Computer Anxiety: Development and Validation of the Computer Anxiety Rating Scale." Computers in Human Behavior 3: 49-59.

ISO. 2010. Ergonomics of Human-System Interaction - Part 210: Human-centred Design for Interactive Systems. ISO 9241-210:201.

Jefferson, A., and R. Pollock. 2014. 70:20:10: Where is the Evidence? Association for Talen Development. https:// www.td.org/Publications/Blogs/Science-of-Learning-Blog/ 2014/07/70-20-10-Where-Is-the-Evidence.

Jennings, C., and J. Wargnier. 2011. "Effective Learning with 70:20:10. The New Frontier for the Extended Enterprise." CrossKnowledge.

Kajewski, K., and M. Valerie. 2013. Demystifying 70:20:10 White Paper. Deakin University.

Kotrlik, J. W., and M. N. Smith. 1988. "Computer anxiety Levels of Vocational Teachers." Journal of Agricultural Education 30 (2): 41-48.

Larner, D., and L. Timberlake. 1995. Teachers with Limited Computer Knowledge: Variables Affecting Use and Hints to Increase Use. Curry School of Education, University of Virginia. http://eric.ed.gov/?id=ED384595.

Lazarus, R. S. 2007. Emotion and Adaptation. London: Oxford University Press.

Lewin, K. 1946. "Action Research and Minority Problems." Journal of Social Issues 2 (4): 34-46.

Lombardo, M. M., and R. W. Eichinger. 1996. "The Career Architect Development Planner. Minneapolis, MN: Lominge. Marcotte, E. 2011. "Responsive Web Design." A Book Apart.

Méndez, A., B. Jimenez de Cisneros, C. Fernández, C. Molleda, E. Sadornil, E. Manrique, T. Montoro, and R. Torres. 2011. "A Model for Evaluation of Generic Competences in Engineering: Application to the Problem. Solving competence at the technical University of Madrid." In EDULEARN11, 135-143, October 4-6, Barcelona, España. ISBN 978-84-615-0441-1.

Moriana Elvira, J. A., and J. Herruzo Cabrera. 2004. "Estrés y burnout en profesores." International Journal of Clinical and Health Psychology 3 (4): 597-621.

Mukhopadhyay, S. C. 2015. "Wearable Sensors for Human Activity Monitoring: A Review." IEEE Sensors Journal 15 (3): 1321-1330.

Muresan, M., and E. Gogu. 2013. "E-learning Challenges and Provisions." Procedia - Social and Behavioral Sciences 92: 600-605.

Osborn, A. 2007. Your Creative Power. How to Use Imagination. Nueva York: Myers Press. 
Paraskeva, F., H. Bouta, and A. Papagianni. April 2008. "Individual Characteristics and Computer Self-efficacy in Secondary Education Teachers to Integrate Technology in Educational Practice." Computers \& Education 50 (3): 1084-1091.

1005 Polya, G. 2014. How to Solve it: A New Aspect of Mathematical

AQ16 Method. Princeton, NJ: Princeton University Press.

^ Prensky, M. 2001. "Digital Natives, Digital Immigrants." On the Horizon 7 (5): 1-6.

Rahimi, M., and S. Yadollahi. 2011. "Computer Anxiety and ICT Integration in English Classes among Iranian EFL Teachers." Procedia Computer Science 3: 203-209.

Reichheld, F. F. 2003. "The One Number You Need to Grow." Harvard Business Review 81: 46-54.

Revilla, O. 2010. WCAG 2 Made Easy. Madrid: Itakora Press.

Revilla Muñoz, O., F. Alpiste Penalba, J. Fernández Sánchez. 2016. "The SCAT-ICT Recommender System: An online support program for teachers with personalized recommendations." New Review of Hypermedia and Multimedia 22

AQ18 (1-2): 83-110.

1 Rogers, E. 1962. Diffusion of Innovations. New York: Free Press. Rosen, L., and M. Weil. 1995. "Computer Availability, Computer Experience and Technophobia among Public School Teachers." Computers in Human Behavior 11 (11): 9-31.

Rovai, A. P., and M. D. Childress. 2003. "Explaining and Predicting Resistance to Computer Anxiety Reduction among Teacher Education Students." Yournal of Research on Technology in Education 35: 226-235.

1025 Russell, F., and G. Bradley. 1997. "Teachers' Computer Anxiety: Implications for Professional Development." Education and Information Technologies 2 (1): 17-30.

Sabzian, F., and A. P. Gilakjani. 2013. "Teachers' Attitudes about Computer Technology Training, Professional Development, Integration, Experience, Anxiety, and

1030 Literacy in English Language Teaching and Learning." International Journal of Applied Science and Technology 3 (1): 67-75.

Salanova, M., S. Llorens, and E. Cifre. 2013. “The Dark Side of Technologies: Technostress among Users of Information and Communication Technologies." International Journal of Psychology 48: 422-436.

Salanova, M., S. Llorens, E. Cifre, C. Nogareda, and E. d. WoNT. 2007. Nota Técnica de Prevención 730: Tecnoestrés: concepto, medida e intervención psicosocial. Madrid: INSHT.

Salmeron-Majadas, S., M. Arevalillo-Herráez, O. C. Santos, M. Saneiro, R. Cabestrero, P. Quirós, D. Arnau, and J. G.

1040 Boticario. 2015. "Filtering of Spontaneous and Low Intensity Emotions in Educational Contexts." In AIED. LNCS 9112, edited by Cristina Conati, Neil Heffernan, Antonija Mitrovic, and M. Felisa Verdejo, 429-438. Springer International Publishing. http://link.springer.

AQ19 com/chapter/10.1007\%2F978-3-319-19773-9_43.

1045 A Sánchez, L. Y. 2008. Las condiciones de salud laboral del colectivo de trabajadores de la enseñanza de la Comunidad de Madrid. Madrid: FETE-UGT.

Santos, O. C. 2016. "Emotions and Personality in Adaptive eLearning Systems: An Affective Computing Perspective." In Emotions and Personality in Personalized Systems, edited by Košir, 278-279. Cham: Springer.

Santos, O. C., and J. G. Boticario. 2015. "Practical Guidelines for Designing and Evaluating Educationally Oriented

Recommendations.” Computers \& Education 81: 354-374. ISSN 0360-1315.

Santos, O. C., M. Saneiro, J. G. Boticario, and M. C. RodriguezSanchez. 2016. "Toward Interactive Context-aware Affective Educational Recommendations in Computerassisted Language Learning." New Review of Hypermedia and Multimedia 22 (1-2): 27-57.

Schroer, W. 2008. Defining, Managing, and Marketing to Generations $X, Y$, and $Z$. The Portal, 10, 9. Accessed February 2, 2015. http://goo.gl/Fc40dB.

Torkzadeh, G., and I. E. Angulo. 1992. "The Concept and Correlates of Computer Anxiety." Behaviour and Information Technology 11 (2): 99-108.

Ursava, Ö. F., and H. Karal. 2009. “Assessing Pre-service Teachers' Computer Phobia Levels in terms of Gender and Experience, Turkish Sample." International Journal of Behavioural, Cognitive, Educational and Psychological Sciences 1: 71-75.

Ventura, M., S. Llorens, and M. Salanova. 2006. El tecnoestrés: un estudio del desarrollo de diferentes instrumentos de medida. 11 Jornades de Foment de la Investigació.

Wilfong, J. D. 2006. "Computer Anxiety and Anger: The Impact of Computer Use, Computer Experience, and Self-efficacy Beliefs." Computers in Human Behavior 22 (6): 1001-1011.

\section{Appendix. Analysis of ICT support programmes for teachers in Spain}

There are five categories of support programmes in Spain for teachers, as shown in Table A1. Each category is oriented towards a different profile and their goals and resources are different. In Tables A2-A6, initiatives are reported and summarised in terms of these five categories, as follows: (i) initial education for teachers (Table A2), (ii) lifelong learning for teachers (Table A3), (iii) governmental ICT promotion in schools (Table A4), (iv) private ICT promotion for teachers (Table A5); and (v) communities of practice (Table A6).

Table A1. Categories of support programmes.

Category Description

Initial education for The Master to provide the diploma to practise teachers the profession of Professor of Secondary Education must contain the specific subject 'Research and innovation in education and management change', with the aim of providing the teachers with strategies and techniques to enhance their work with ICT.

Lifelong learning for teachers

Governmental ICT promotion in schools

Private ICT promotion for teachers

Communities of practice Courses for teachers can be divided into four categories: general software, educational software, how to apply ICTs in the teaching of different subjects, and digital culture.

The promotion of ICT in educational institutions has focused on three aspects: to provide information and administrative processes through the Internet, to provide technology infrastructure, and to provide training and tools for teachers and students.

1


Table A2. Initial education for teachers.

\begin{tabular}{|c|c|c|}
\hline Institution & Review & Subjects analysed \\
\hline $\begin{array}{l}\text { Universitat } \\
\text { Politècnica de } \\
\text { Catalunya }^{a}\end{array}$ & $\begin{array}{l}\text { It does not offer a certain } \\
\text { ICT-centred subject, but } \\
\text { introduces ICT } \\
\text { transversely within the } \\
\text { subjects. }\end{array}$ & $\begin{array}{l}\text { - Introduction to } \\
\text { educational innovation } \\
\text { and research in the } \\
\text { field of mathematics } \\
\text { - Society, family, and } \\
\text { education } \\
\text { - Mathematics for the } \\
\text { twenty-first century }\end{array}$ \\
\hline
\end{tabular}

Universitat Autònoma de Barcelona $^{\mathrm{b}}$

Universidad Nacional de Educación a Distancia $^{c}$

It focuses the ICT syllabus in two subjects, one of specialty didactic apart of the traineeship. ICT are introduced transversely. ICT-centred subject, but introduces ICT transversely within the subjects. and social psychology

- Biology, and geology and its teaching
- Training in pedagogical

motivation in the classroom

- Teaching innovation and introduction to
Universidad de Almería
Universidad de La It does not offer any Rioja ${ }^{\mathrm{d}}$ psychology and other

It does not offer a certain - Learning and subject in ICT. It is part of the syllabus of certain subjects.
Table A3. Lifelong learning for teachers.

Category Programmes

Digital culture

- Electronic administration and information management $^{a}$

- Data privacy

Instrumental applications not necessarily linked to the educational world, but focused on education

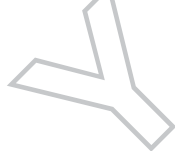
educational research

- Design and development of the curriculum

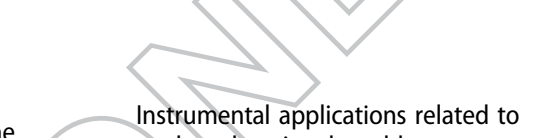

the educational world

- Web 2.0 for educational centres

- Webdesign with Photoshop ${ }^{\mathrm{d}}$

- Open Office ${ }^{e}$

- Web 2.0 as a tool for education ${ }^{f}$

- Social Networks ${ }^{g}$

- Building and programming robots with Lego Mindstorms ${ }^{h}$

- Robots to teach technology and science ${ }^{i}$

- Internet as an educational tool

- Introduction to Adobe Flash ${ }^{\mathrm{k}}$

- Electronic whiteboards as interactive educational tools'

- Learning communities ${ }^{m}$

- Webquest ${ }^{\mathrm{n}}$

- Librarianship and Web $2.0^{\circ}$

Teaching methodology in which ICTs are applied

- ICT in the classrooms ${ }^{p}$

- How to teach with Internet ${ }^{q}$

- Master in ICT and education ${ }^{r}$

- Master in ICT and knowledge

- E-learning education ${ }^{t}$

- Teaching Grammar ${ }^{\mathrm{u}}$

- Teaching Maths ${ }^{\mathrm{V}}$

- ICT in education ${ }^{w}$

- European Master in ICT and education ${ }^{x}$ and introduction to educational research.

- Teaching innovation and introduction to educational research

It has two subjects focused on acquiring competences in ICT. Besides its subjects enclose transversal

- ICT resources in the classroom education in ICT.
${ }^{a}$ http://mfp.masters.upc.edu/informacio-academica.

${ }^{b}$ http://www.uab.es/servlet/Satellite/informacion-academica-de-los-masteres -oficiales/la-oferta-de-masteres-oficiales/plan-de-estudios/formacion-del-pr ofesorado-de-educacion-secundaria-obligatoria-y-bachillerato-formacion-p rofesional-y-ensenanzas-de-idiomas-1096480309783.html?param 1=123606 5658068 .

chttp://portal.uned.es/portal/page?_pageid=93,27108104\&_dad=portal\&_sc hema $=$ PORTAL\&idMaster $=230401$.

d www.unirioja.es/estudios/master/2012_13/M0nA.shtml.

ehttp://cvirtual.ual.es/guiado/servlet/bin?id=6287_CAS.
ahttp://gestion.forem.es/fee2012/utiles/documentos/ADMINISTRACI\%C3\% 93N\%20ELECTR\%C3\%93NICA,GESTI\%C3\%93N\%20DE\%20LA\%2OINFORMA Cl\%C3\%93N.pdf.

b http://www.fsie.es/archivos/LEY\%20PROT\%20DATOS.pdf.

chttp://gestion.forem.es/fee2012/utiles/documentos/WEB\%202.0\%20EDICI\% C3\%93N\%20DE\%20P\%C3\%81GINAS\%20EN\%20LOS\%20CENTROS\%20EDU CATIVOS.pdf.

${ }^{d}$ http://www.fsie.es/archivos/PHOTOSHOP.pdf.

ehttp://www.fsie.es/archivos/OPEN\%200FFICE.pdf.

$f_{\text {http://www.fsie.es/archivos/WEB\%2020.pdf. }}$

${ }^{9} \mathrm{http} / / /$ www.formacionpermanentedelprofesorado.es/Curso-Redes-Sociales.

${ }^{h}$ http://gcice.upc.edu/fitxa_cursos.asp?id= $=52842 \& \mathrm{np}=1$.

'http://gcice.upc.edu/fitxa_cursos.asp?id=52723\&np=1.

${ }^{\mathrm{h}}$ http://gestion.forem.es/fee2012/utiles/documentos/EL\%20USO\%20DE\%20IN TERNET\%20COMO\%20HERRAMIENTA\%20DIDACTICA.pdf.

khttp://gestion.forem.es/fee2012/utiles/documentos/INTRODUCCI\%C3\%93N $\% 20$ \%20ADOBE\%20FLASH.pdf.

'http://www.fsie.es/archivos/PIZARRA\%20DIGITAL.pdf.

mhttp://www.formacionpermanentedelprofesorado.es/Curso-de-Experto-enComunidades-de-Aprendizaje-Learning-Community.

nhttp://gestion.forem.es/fee2012/utiles/documentos/WEBQUEST.\%20DISE\% C3\%910\%20Y\%20UTILIZACI\%C3\%93N\%20DID\%C3\%81CTICA.pdf.

$\mathrm{http}: / /$ www.formacionpermanentedelprofesorado.es/Curso-de-Aplicacionde-las-Bibliotecas-Escolares-y-Web-20.

Phttp://www.formacionpermanentedelprofesorado.es/Aplicacion-Didactica-Tic.

9https://adenu.ia.uned.es/web/es/members/jgb/teaching/ongoing_education/ aprender_formar_internet/temario.

'http://www.uned.es/infoedu/planes.htm.

shttp://www.uned.es/infoedu/i-planes.htm.

thttp://www.formacionpermanentedelprofesorado.es/Curso-Formacion-Elearning.

uhttp://www.fsie.es/archivos/DIDAC\%20LENGUA.pdf.

vhttp://www.fsie.es/archivos/DIDAC\%20MATEMATICAS.pdf.

whttp://gestion.forem.es/fee2012/utiles/documentos/NUEVAS\%20TECNOLOG\% C3\%8DAS\%20APLICADAS\%20A\%20LA\%20EDUCACI\%C3\%93N.pdf.

xhttp://www.formacionpermanentedelprofesorado.es/Curso-de-Master-Europe o-en-Nuevas-Tecnologias-Aplicadas-la-Educacion. 
Table A4. Governmental ICT promotion in schools.

\begin{tabular}{lc}
\hline Programme & \multicolumn{1}{c}{ Organisation } \\
\hline Good practices in the web ${ }^{\mathrm{a}}$ & INTEF - National Institute for the Teachers'
\end{tabular}

Training and Educational Technologies ${ }^{\mathrm{b}}$

EducaconTIC

Ministry of Industry, Energy, and Tourism; Ministry of Education, Culture, and Sport
Astrolabi $^{\mathrm{a}}$ observatory

ONTEV ${ }^{\mathrm{e}}$ observatory

Internet at the classroom Social Network ${ }^{f}$

'Internet at the classroom' annual Congress ${ }^{9}$
Jaume Bofill Foundationa and Universitat Oberta de Catalunya Valencian Educational Quality Institute

INTEF attp://recursostic.educacion.es/buenaspracticas20/web/.

${ }^{b}$ http://www.ite.educacion.es/.

chttp://www.educacontic.es.

${ }^{d}$ http://astrolabi.edulab.net/int_inf_index.htm.

'The official web http://ute.uv.es/ontev is not online, but an archived copy can be found at http://web.archive.org/web/20100409060523/http://ute.uv.es/ontev/ ontev_c/indexc.htm.

fhttp://internetaula.ning.com/.

${ }^{9}$ Although the official web http://www.congresointernetenelaula.es is not online, an archived copy can be found at https://web.archive.org/web/ 20090428031348/http://www.congresointernetenelaula.es/virtual/?.
INTEF's goal is the development and dissemination of materials in digital and audiovisual support in all areas of knowledge, in order that the information technology and communication are an ordinary working tool in the classroom for teachers of different educational stages. Besides, it conducts specific training programmes in collaboration with the Autonomous Communities in the field of classroom application of Information Technology and Communication.

- It is a portal that collects experiences with technology in the classroom.

These two ministries have founded a web portal that aims to be a forum for the dissemination and exchange of good educational practices where ICT are the main protagonists. Its two main sections are the blog and catalogue.

-The blog collects news and presents educational resources; websites analysed reference explains authoring tools .... It is a good site for teachers to keep abreast of technologies applied to education.

In the ICT catalogue all kinds of materials can be found in any format. Its contents are organised around educational levels and resource types.

For three years, Astrolabi group monitorised the ICT implantation in High Schools and how it affected different stakeholders in Catalonia.

For two years, ONTEV group monitorised the ICT implantation in High Schools and how it affected different stakeholders in Valencia.

It is a social network integrated by teachers from different types of areas, courses, and materials, organised by groups. Its main objective is to provide a virtual meeting place for any teacher to freely participate, to share expertise and resources, and to contact and collaborate with other teachers with similar interests.

Although it was discontinued in 2008, it congregated the most innovative projects on education. Its goals were, among others:

- Encourage the use of ICT in education.

- Disseminate the achievements of the Internet in the Classroom programme.

- Facilitate teaching approach to the Information Society and Communication.

- Recognise the figure of teachers as the main agents of educational innovation through the use of ICT.

- Highlighting the support technology can provide to the implementation of curricula derivatives Education Act.

- Help achieve the core competencies of the new curriculum by incorporating ICT.

- Encourage the implementation of good educational practice experiences.

- Show the effectiveness of ICT in improving learning.

- Contacting communities of teachers engaged in the educational use of ICT.

- To present the best international initiatives for innovation through the use of ICT.

Promote a general reflection on the teaching and the current needs in education. 
Table A5. Private ICT promotion for teachers.

\begin{tabular}{lc}
\hline Programme & Organisation \\
\hline Educared $^{\mathrm{a}}$ & $\begin{array}{c}\text { Telefonica } \\
\text { Foundation }\end{array}$
\end{tabular}

Profes.net -

${ }^{a}$ http://www.fundaciontelefonica,com/educacion_innovacion/.

chttp://www.smconectados.com/Soporte_tecnico.html.

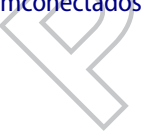

It focuses on the interplay of three key components: technology, pedagogy, and educational content. Its goal is to promote interaction between teachers, students, parents, and schools to boost the search for quality cited in nonuniversity education.

It is organised around three sections:

- Updates with information on events, awards, and announcements.

- Resources, publications, research, and teaching aids.

- Community Foundation projects, learning environments, and user blogs.

The purpose of the Portal Educared lies in promoting a new educational model that can be extended and replicated globally and that includes both the advantages and changes, and innovations in technologies induce new way to learn. Profes.net was a vertical online portal that offers communication resources, information, and support to teachers of different levels. It is an interesting area for the teachers' computer advisor 'where teachers raise questions about computer and internet portal and an expert answers them ${ }^{\prime c}$. It became SM Conectados in 2013.
Table A6. Communities of practice.

Programme Description

Blogs There are hundreds of teachers who share their thoughts on the net. For this research, we have reviewed the following:

- http://ticsunivo.blogspot.com.es/

- http://edumorfosis.blogspot.com.es/

- http://www.iesgrancapitan.org/blog05/

- http://www.profesorjano.biz/

- http://www.profesorjano.info/

- http://profesorjano.org/

- http://lindacastaneda.com/mushware

- http://villaves56.blogspot.com.es/

Social network There are several groups in social networks of high groups school teachers, as 'Secondary Education Teachers' or 'Secondary Teachers of Andalusia', both from the social network Facebook. Both have a high activity (the first 450 users and 875 the second).

- The first group is defined and functions as a meeting place, information and discussion about the needs of all types having Secondary Education Teachers in Spanish-speaking countries: labour, union, and legal aspects; educational content in different formats, relationships with parents, educational methods ...

- The second one is defined as a support group, where opinions, complaints, suggestions, and recommendations from personal and political exchanged court 'because no one understands us better than ourselves'.

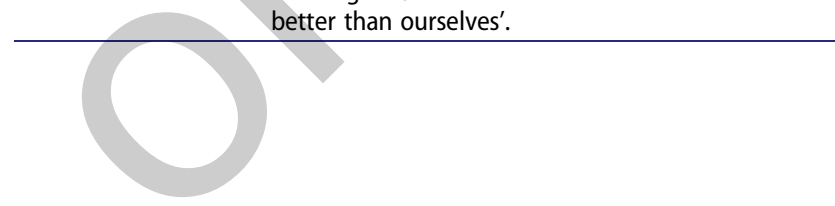

bhttp://www.profes.net/info.html, currently http://www.smconectados.com/. 